\title{
Benthic foraminifera as ecological indicators in the Tunda Island Waters, Serang District, Banten Province, Indonesia
}

\author{
ISNI NURRUHWATI ${ }^{1}$, FACHRI ARDIANSYAH $^{1}$, YUNIARTI $^{1}$, LINTANG PERMATA SARI YULIADI $^{1}$, \\ RUHYAT PARTASASMITA ${ }^{2, \bullet}$ \\ ${ }^{1}$ Department of Fisheries, Faculty of Fisheries and Marine Science, Universitas Padjadjaran. Jl. Raya Bandung Sumedang Km. 21, Jatinangor, Sumedang \\ 45363, West Java, Indonesia \\ ${ }^{2}$ Department of Biology, Faculty of Mathematics and Natural Sciences, Universitas Padjadjaran. Jl. Raya Bandung Sumedang Km. 21, Jatinangor, \\ Sumedang 45363, West Java, Indonesia. Tel./fax.: +62-22-7797712. `email: ruhyat.partasasmita@unpad.ac.id; rp2010rikkyo@ gmail.com
}

Manuscript received: 22 April 2020. Revision accepted: 18 June 2020.

\begin{abstract}
Nurruhwati I, Ardiansyah F, Yuniarti, Yuliadi LPS, Partasasmita R. 2020. Benthic foraminifera as ecological indicators in the Tunda Island Waters Serang District, Banten Province, Indonesia. Biodiversitas 21: 3142-3148. Coral reef communities all across Southeast Asia are experiencing intense pressures from extensive tourism and massive coastal development. A prediction regarding coral reefs' capacity to recover is a necessity since it is constantly exposed to damaging events such as mass bleaching and increased erosion. Tunda Island (which is highly rich in biodiversity and include coral reefs, mangrove forests, seagrass, and algae meadows) was sampled at 10 different sites in August 2019. Coral reefs are highly influenced by ecological factors such as temperature variability, salinity, DO, and $\mathrm{pH}$. The assessments were conducted using the FORAM Index (FI) to accurately predict the capacity of coral reefs to recover based on relative abundances of symbiont-bearing larger benthic foraminifera in reef sediments. The FI values ranged from 3.7 to 7.9 with a median of 4.7 and the average of 5 indicates that the water quality should support the recovery of reefs by reef-building corals and symbiont-bearing larger benthic foraminifers. The lowest FI value sampled was recorded from a site with extensive human activities (FI=3.4), while the highest one was recorded from a site with minimal to none human activities (FI=7.9), which indicates that the deterioration of water quality is caused by wastes from tourism activities near the coastal area
\end{abstract}

Keywords: Coral reef communities, water quality, foraminifera, FoRAM index

\section{INTRODUCTION}

Coral reefs are vital marine ecosystems that are in serious decline; it is estimated that $30 \%$ of them are already severely damaged and almost $60 \%$ may be lost by the year of 2030 (Hughes et al. 2003). The study of coral reef ecosystems provide important insights for their conservation and shall drive preventive actions before its deterioration (Pisapia et al. 2017). Coral reef ecosystems may appear normal and healthy even long after significant deterioration has occurred (McClanahan et al. 2011) Evidence has shown that changes and dramatic losses in these ecosystems emerged in the 1970s. (Rogers 1990). The efforts to protect coral reefs for the last 30 years have failed to make a real difference in reversing regional scale declines, management of reefs on a global scale needs to be changed radically to make a significant impact, new approaches for sustainable management must be done to evaluate the condition of these important natural resources (Hughes et al. 2003).

The primary triggering condition for large-scale mass bleaching events is the combination of high solar irradiance and anomalously warm sea surface temperatures (HoeghGuldberg 1999). Such sensitivity makes coral reefs vulnerable to future climate change, with some scientists predicting that global warming trends could see the majority of the world's coral reefs severely degraded or even transformed to non-coral dominated states by as early as 2030 (Hoegh-Guldberg et al. 2007). Perhaps more in hope than expectation, the opinion has commonly been expressed that improved coral reef management, by delivering conditions that favor the recovery of coral reefs following disturbance, could forestall the onset of such a catastrophe (Marshall and Schuttenberg 2006). In many cases, it is tough to determine reference conditions against which changes can be calculated because the different components of ecosystems often respond differently to changes in marine environments (Dayton et al. 1998).

Changes in microscopic communities such as microbe and foraminifera are significant to coral reef conditions. These changes are crucial information to understand how the whole coral reefs' system changes, such as those affected by nutrification. Nutrification occurs either through direct nutrients addition (Dubinsky and Stambler 1996) or through changes in trophic cycling and nutrient cycles (Kitchell et al. 1979; Chapin et al. 1997). The relative abundance of viruses and heterotrophic increases with human impacts, like fishing and pollution (Carlson et al. 2002; Dinsdale et al. 2008, Graham et al. 2011). in response to reduced water quality on coral reefs, benthic foraminiferal communities may change (Hallock et al. 2003; Uthicke and Nobes 2008), providing a mechanism to test for nutrification on reefs. We investigated the conditions of benthic foraminiferal communities in Tunda Island waters. 
When reefs get exposed to intense human pressure from tourism activities or in proximity to civilians, it may recover slowly due to run off and/or pollution (Sandin et al. 2008). Most of the knowledge of coral reefs and their adaptability got acquired from Australia's Great Barrier Reef and Caribbean (Hughes 1994; Mumby et al. 2007; Sweatman et al. 2011; De'ath et al. 2012). On the contrary, so little had already been investigated about the coral reefs communities in the Indo-Pacific Waters. Coral reefs communities in Indonesia are some of the most diverse in the Indo-Pacific Waters, hosting more than 590 species of corals which populates $51 \%$ of coral reefs communities in Southeast Asia and $18 \%$ in the world (Estradivari et al. 2018). Currently, Indonesia's coral reefs communities Indonesia, are experiencing threats of being damaged both due to human pressure and natural factors that cannot be avoided (Grace 2015). According to Hermansyah et al. (2017), the condition of coral reefs communities in Tunda Island waters has experienced degradation and decline due to threats and pressures from nature and human activities such as tourism activities which might have caused the overall deterioration of the marine environment. Tunda Island is one of the Serang Coastal Zoning Areas (RZWP3K) which was issued legally by Banten Provincial Government aimed to protect, conserve, rehabilitate, utilize and enrich coastal resources, small islands, and their ecological systems sustainably. Considering the limitations for large-scale coral reefs management, understanding the bioecological influences directing reef resilience important for the suitable management of Tunda Island reefs.

Benthic foraminifera is unicellular protists, many of which are very sensitive to changes in environmental conditions and their shells can be used as standard tools for oceanographic reconstruction (Prazeres et al. 2020). Foraminifera builds calcium carbonate shells, and are an important component of the benthos (Murray 2014). In tropical reef environments, larger benthic foraminifera are more often than not dominant, larger benthic foraminifera has environmental requirements similar to those of reefbuilding corals as they make use of algal endosymbionts (Prazeres and Renema 2019). Foraminiferal diversity, abundances, and assemblage level are sensitive to changes in food resources and water transparency, combined with the accumulation of foraminifera in the sediments, make foraminifera effective and natural bioindicators of water quality in coral reefs environments (Alve 1995; Schaffer, 2000). Foraminifera in Reef Assessment and Monitoring (FoRAM) Index (FI) was developed by Hallock et al. (2003) to quantify the value of foraminiferal abundance, diversity, and assemblage level to fulfill the need for effective bioindicators for coral reefs and its water quality (Kurtz et al. 2001). Hallock (2012) summarized the use of FI in different environments concluding that its effectiveness has proven to be vastly better than originally developed, despite some limitations (Hallock et al. 2006). The FoRAM Index is based on the fact that large benthic foraminifera which hosts algal endosymbionts, that are plentiful on healthy coral reefs, need water-quality conditions akin to those required by coral reefs (e.g., Hallock 1984; Hallock et al. 2003; Fujita et al. 2016). Nutrients that enter coral reef environments allow the rapid proliferation of heterotrophic foraminifera, whose shells are vastly greater in number than those of endosymbiontbearing taxa (Cockey et al. 1996). Only under cases with acute regional nutrification, a few species of small, stresstolerant foraminifera can become dominant (e.g., Alve 1995; Carnahan et al. 2009). Benthic foraminifera is effective as bioindicators because of their short life cycles and high sensitivity to changes in water quality, thus allows them to respond faster than corals to environmental changes (Prazeres et al. 2020). The FI is based on the abundance and presence of three functional taxa groups which are symbiont-bearing, stress-tolerant, and other small foraminifera in sediments collected within coral reefs communities (between 5 and $15 \mathrm{~m}$ depth). The percentages of the three functional groups in reef sediments provide an effective and efficient tool to differentiate between healthy reefs, reefs in decline, and severe coral-specific degradation. (Hallock 2012; Pisapia et al. 2017; Beccari et al. 2020).

The purpose of this research is to evaluate the FI in Tunda Island waters, to assess the reef conditions across spatial variation The FI was determined for sediments in different locations around the island with different amount of human activities, and different coral coverages to test if it can predict the coral reefs' resilience in Tunda Island waters.

\section{MATERIALS AND METHODS}

\section{Sampling area}

The research was carried out in the waters of Tunda Island, Banten in August 2018. Tunda Island is the outermost of the 17 islands in Serang District, Banten Province. It is located in the Java Sea north of Serang Regency, which is at $05^{\circ} 48^{\prime} 44^{\prime \prime S}$ and $106^{\circ} 16^{\prime} 47^{\prime \prime E}$ (Figure 1.). Tunda Island has an area of $257.5 \mathrm{Ha}$, consisting of one village named Wargasara Village and is divided into 2 villages (western and eastern) (DLHK Banten 2017). On Tunda Island, in addition to domestic activities, there are also ports and industrial areas. Serang Regency is considered a strategic location according to Government Regulation Number 47 of 1997, concerning National RT / RW. Ten reef sites were chosen (Figure 1) based on the population and activities of humans on Tunda Island. Research sampling was conducted following the research procedure described in Pisapia et al. (2017). The sediment was sampled at $10 \mathrm{~m}$ depth with a scoop by SCUBA divers. Scuba divers scooped the upper 1-2 centimeters of the surface sediments into a plastic bag. 


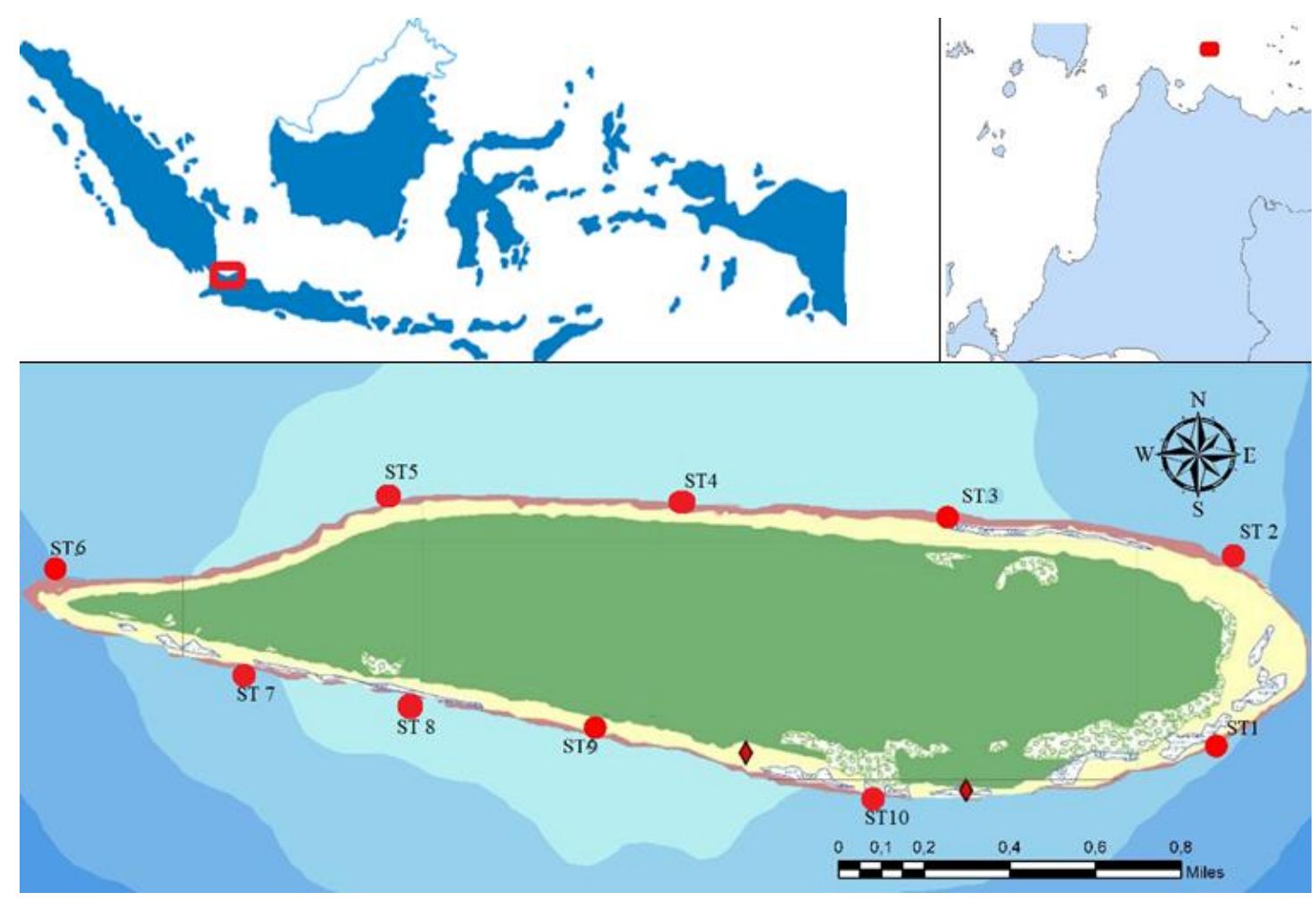

Figure 1. Map of Tunda Island, Banten Province, Indonesia (05 $48^{\prime} 44^{\prime \prime} \mathrm{S}$ and $\left.106^{\circ} 16^{\prime} 47^{\prime \prime} \mathrm{E}\right)$

\section{Grain size analysis}

Samples of sediments from ten sites were drily sieved, using standard mesh sizes based on Prazeres et al. (2020) who stated that FI should include grain-size analysis and sediment samples that are sorted well, very coarse (>2 mm) sediments should not be included from analysis, as should samples that are predominantly mud $(<0.63 \mathrm{~mm})$. Thus, mesh sizes of $2 \mathrm{~mm}, 1 \mathrm{~mm}, 0.5 \mathrm{~mm}, 0.25 \mathrm{~mm}, 0.125 \mathrm{~mm}$, and $0.063 \mathrm{~mm}$ were chosen for this research. Each of the grain size's weight was measured and the percentage of each fraction's weight was calculated to get the grain size for each site (Table S2).

\section{Foraminiferal analyses}

Each sediment sample from its respective site was examined. All benthic foraminiferal specimens from the $>125-\mu \mathrm{m}$ fraction were handpicked from each sediment sample and got identified under a binocular microscope; 150-200 foraminiferal individuals were picked following the standard protocol. Dix (2001) demonstrated that this amount provides a statistically valid compromise between the precision of larger samples and processing costs in low diversity samples, or when not identifying to species level (Hallock et al. 2003). The total foraminiferal assemblages were examined in each sample which presented useful information about the changing conditions of coral reefs in Tunda Island waters. The identification was based on the foraminiferal test characteristics like chamber arrangement, structure, and aperture position (Loeblich and Tappan 1988). This procedure was adopted to investigate the complete assemblage of the benthic foraminifera. The picked benthic foraminiferal specimens were categorized into genus and one of three functional groups (symbiontbearing, stress-tolerant, or other smaller taxa) and counted. The FoRAM Index was calculated according to its functional groups as stated by Hallock et al. (2003) the FI was calculated with this equation:

$$
\mathrm{FI}=(10 \times \mathrm{Ps})+(\mathrm{Po})+(2 \times \mathrm{Ph})
$$

Where; Ps, Po, and $\mathrm{Ph}$ represent the number of symbiont-bearing, stress-tolerant, and other heterotrophic taxa, respectively. (Hallock 2012; Reymond et al. 2012). A coral reef with FI > 4 indicates an oligotrophic condition generally favorable for calcifying organisms that host algal endosymbionts, an FI between 2 and 4 indicates a marginal condition, while FI $<2$ indicates environmental conditions that are unfavorable to calcifying that host algal endosymbionts and support a significant amount of populations of stress-tolerant foraminifera (Hallock et al. 2003).

\section{Data analyses}

FoRAM Index values and grain sizes were analyzed statistically to determine correlations between each parameter. To investigate how FI and grain size are correlated, a Principal Component Analysis (PCA) was done to determine how each sample varied among sites, this is important since endosymbiont-bearing foraminifera are larger in size compared to other functional groups (stress-tolerant and other smaller taxa). A PCA was also conducted to determine how FI sediment textures are 
correlated among 10 sites. All PCA calculations were done using the XLSTAT add-on on Microsoft Excel.

\section{RESULTS AND DISCUSSION}

\section{Results}

In Tunda Island waters, benthic foraminiferal assemblages are diverse; 53 species were identified classified according to the three functional groups (symbiont-bearing, stress-tolerant, or other smaller taxa). The endosymbiont-bearing taxa functional group was dominated by Peneroplis spp. , Amphistegina lessonii and Calcarina calcar, with Operculina spp.'s occurrences happen more rarely. The heterotrophic taxa functional group was fairly limited, which included Elphidium spp., Ammonia spp. and bolivinids. And stress-tolerant taxa obtained in the sites partly consist of Pseudorotalia schroeteriana, Quinqueloculina spp., and Neoconorbina petasiformis.

The most abundant symbiont-bearing foraminifera found in Tunda Island waters is Peneroplis spp. , Amphistegina lessonii, and Calcarina calcar (Table S1) According to Prazeres et al. (2020), the abundance of LBF species of the family Calcarinidae found in the indo-pacific region might skew the overall FI values. Renema (2010) stated that calcarinids thrive in environments where mesotrophic conditions and algal overgrowth preclude coral recruitment. Therefore, all calcarinid specimens in this research are removed from the final FI calculation because there is no a-priori historical information in regards to foraminiferal conditions in Tunda Island.

The FI measured for samples collected along the sites on Tunda Island waters ranges between 3.7 and 7.4, with a median of 4.7 (Table S2). Hallock et al (2003) stated that the sample with a value of FI that shows ideal conditions for the growth of coral reefs waters contains at least 25$30 \%$ endosymbiont-bearing foraminifera specimens, which

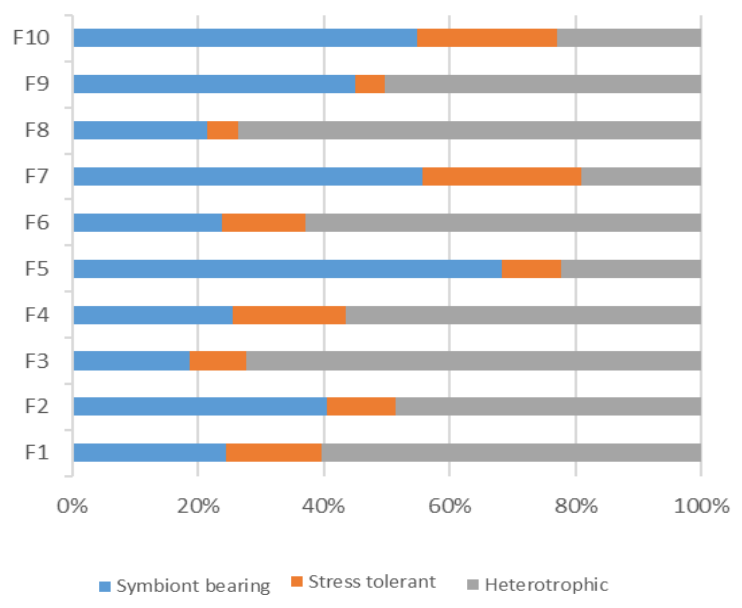

Figure 2. Relative Abundance of benthic foraminifera in Tunda Island waters based on the three functional groups in this case was found to be most of the sites in Tunda Island waters (F10, F7, F5, F6, F2) (Figure 2; Table S1). The highest FoRAM Index (FI) in Tunda Island waters is from station 5, which is 7.4. This station has an abundance of benthic symbiont-bearing foraminifera with a percentage of $68.3 \%$ (Figure 2.). The lowest FI value in the waters of Pulau Tunda is found at station 3, which is 2.1 , with the percentage of symbiont-bearing foraminifera of $18.7 \%$.

The PCA comparing water qualities to FI indicated high correlations between $\mathrm{pH}$ and FI values since the FI and $\mathrm{pH}$ vector lines are long and close (Figure 3). The PCA comparing grain size to FI indicated some positive correlations between FI and fine sand vector. The grainsizes were predominantly medium $(250-500 \mu \mathrm{m})$ to coarse $\left(500 \mu \mathrm{m}^{-1} \mathrm{~mm}\right)$ sands (Table S2). No significant clusters were seen in both PCA (Figures 2 and 3). The FI vector is long and forming a small angle with the coarse sand vector (500 $\left.\mu^{-1} \mathrm{~mm}\right)$; showing a high and positive correlation. The FI vector diverging forming a large angle (close to $\left.180^{\circ}\right)$ with the fine sand vector $(<63 \mu \mathrm{m})$ indicates that they are negatively correlated.

\section{Discussion}

The human activities that are conducted on Tunda Island are diving, fishing, and sand mining, which intensities are varied across different sites. These activities may generate problems which make investigating anthropogenic threats is a must. Previous studies have assessed the FI across a range of anthropogenic influences (Pisapia et al. 2017). The FI reflects how the coral reefs environments changes over a certain period of time which can be months even years, this is because time-averaged foraminiferal assemblages are the basis of FI (Hallock et al. 2003; Ramirez et al. 2008; Beccari 2020). Sediment texture has effects to some degree to the value of FI (Beccari, 2020). Prazeres et al. (2020) recommended that the use of FI as an ecological tool should incorporate grain-size analysis.

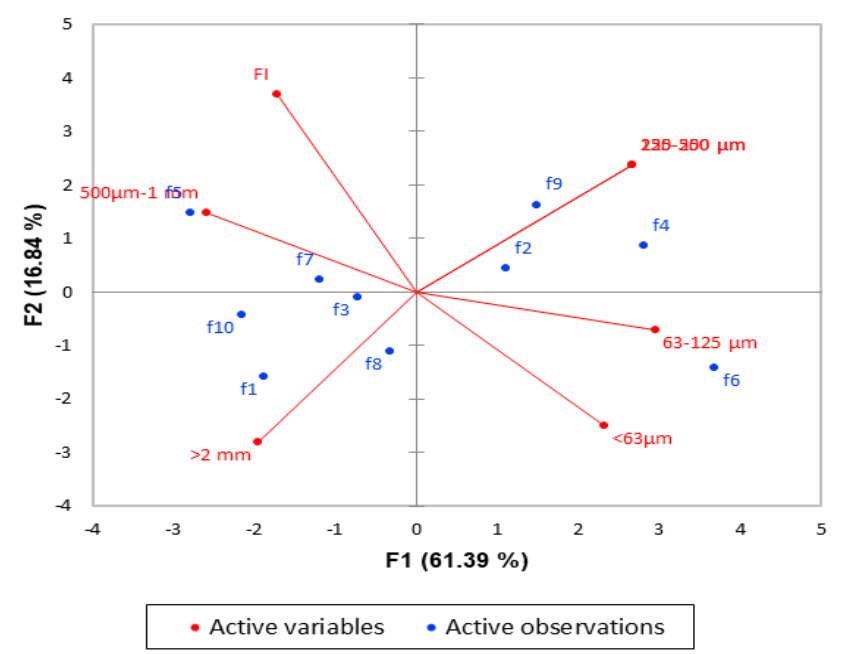

Figure 3. Principal Component Analysis comparing grain size and FI 
Beccari et al. (2020) stated that measuring the water qualities for the application of the FI is unnecessary since Pisapia et al. (2017) showed that in-situ water parameters measured at the 2015 Maldives research campaign are practically similar and within the typical ranges of reefs and within the typical ranges of water qualities of previous researches conducted in the Maldives and the other Indian Ocean regions. Therefore, water qualities are not discussed here.

The median FI values of 4.7 indicate that the water quality of the reef communities in Tunda Island currently supports growth of healthy reefs (Table S2). However, the FI values overall were somewhat higher in areas with lower human activities and lower near community, resort islands, and sand mining sites, indicating degradation in coral reef environments conditions in areas with intense human pressure (Table S2; Figure 1). Pisapia et al. (2017) stated that the lower FI values at certain sites may be caused by the limited measures of domestic waste disposal, as the subsequent agglomeration of waste near an island can generate very local nutrification (Boblme 2010; Pisapia et al. 2017). Emrich et al. (2017), demonstrated that FI and fecal sterols correlate negatively. The overall average of the FI values was 5, which indicates that reef sites with limited land area and generally exposed to currents and waves will get a highly limited influence of sewage pollution. The medium-to-coarse sediment texture, which was recorded at most sites in Tunda Island waters, also indicates a vigorous ocean dynamic system that can get rid of the influence of local waste. The highest value of FI was acquired from station 5 which is a site with the least human pressure (Figure 1, Table S2).

Pisapia et al. (2017), Hallock et al. (2003), and Carnahan et al. (2009) all proved that FI values are generally higher in coarser sediments than finer sediments. According to Uthicke et al. (2010) and Narayan and Pandolfi (2011), the FI values relatively are negatively correlated with increasing fine sediment amounts. Samples from the Tunda Island waters are predominantly medium to coarse, while the FI vector is highly and positively correlated with the coarse vector (Figure 3), further indicates that FI values are higher in coarser sediments. According to Beccari et al. (2020) and Hohenegger (2006), FI values and amounts of coarser sand are positively correlated because of the ocean dynamic processes that eliminate finer grain sediments, also remove smaller foraminiferal taxa, and leaving large benthic symbiontbearing foraminifera. Clarke et al (2000) also demonstrated that coral mortality increases the cover of filamentous and fleshy algae, thus, heterotrophic individuals will be abundant since there will be more food available for them.

Applying FoRAM Index to evaluate coral reefs habitat has not yet been commonly used in Indonesia. According to Chen and Lin (2017), the environmental and ecological applications of the FI have been unforeseen since its development. Hallock et al. $(2003,2012)$ predicted that modifications of the formula will be required when applying it for reefs other than the ones in western AtlanticCaribbean areas such as Indo-Pacific water, which was done by great detail by Prazeres et al. (2020), Prazeres et al. updated the FI tools with some considerate changes such as the minimum of replicate samples, sediment texture range, the need for preliminary study, minimum of specimens, and calculation for Indo-Pacific region abundant with calcarinids.

This was the first quantitative study on the application of the FoRAM Index as an ecological indicator. Three foraminiferal taxa groups were analyzed, which are; symbiont-bearing, heterotrophic, and stress-tolerant. FI calculations were done to quantify the values to which certain environmental conditions were ideal to provide calcifying symbiosis. A total of 287 species were recorded. The moderately high FIs calculated in this study show that water quality around the reefs in the Tunda Island waters is sufficient to continue to support the growth of healthy coral reefs. Although, the FI values are generally lower near areas with high human pressure such as resorts, tourism, and sand mining indicating local pollution of waters by the disposal of local domestic wastes. The highest value of FI was acquired from a site with the least human activities (F5).

\section{ACKNOWLEDGMENTS}

We thank Faculty of Fisheries and Marine Science, Universitas Padjadjaran, Sumedang, Indonesia for supporting this research and also the research team for all the assistance during the research.

\section{REFERENCES}

Dayton PK, Tegner MJ, Edwards PB, Riser KL. 1998. Sliding baselines, ghosts, and reduced expectations in kelp forest communities. Ecol Appl 8: 309-322.

De'ath G, Fabricius K, Sweatman H, Puotinen M. 2012. The 27-year decline of coral cover on the Great Barrier Reef and its causes. Proc Natl Acad Sci USA 109. 10.1073/pnas.1208909109.

Dinsdale EA, Pantos O, Smriga S, Edwards RA, Angly F, Wegley L, et al. 2008. Microbial ecology of four coral atolls in the Northern Line Islands. PLoS ONE 3: e1584. DOI: 10.1371/journal.pone.0001584

Dix TL. 2001. The Distribution and Ecology of Benthic Foraminifera of Tampa Bay, Florida. [Dissertation]. University of South Florida, Tampa, FL.

Dubinsky Z, Stambler N. 1996. Marine pollution and coral reefs. Glob Change Biol 2: 511-526

Emrich K, Martinez-Colon M, Alegria H. 2017, Is untreated sewage impacting coral reefs of Caye Caulker, Belize? J Foramin Res 47: 2033.

Estradivari M, Syahrir S, Nugroho S, Yusri S, Timotius. 2009. Jakarta coral reef. Yayasan Terumbu Karang Indonesia. [Indonesian]

Graham NAJ, Ainsworth TD, Baird AH, Ban NC, et al. 2011. From microbes to people: tractable benefits of no-take areas for coral reefs. Oceanogr Mar Biol Ann Rev 49: 105-136

Hallock P, Lidz BH, Cockey-Burkhard EM, Donnelly KB. 2003. Foraminifera as bioindicators in coral reef assessment and monitoring: the FORAM index. Environ Monit Assess 81: 221-238

Hallock P. 2012. The FoRAM Index revisited: Uses, challenges, and limitations. Proc 12th Int Coral Reef Symp, Cairns, Australia, 9-13 July 2012.

Hermansyah C. Utomo, Siddik J, Kusumo S, Lathifa A, Azizah H, Permana DD. 2017. The Condition of Coral Reefs in Tunda Island Waters, Serang Regency, Banten Province. Proceedings of the 2017 National Seminar of Aquatic Ecosystems of Lada Bay and Tunda Island. July 20, 2017, KP3B DKP Banten, Loka PSPL Serang, Banten. [Indonesian] 
Hoegh-Guldberg O. 1999. Coral bleaching, climate change and the future of the world's coral reefs. Mar Freshw Res 50: 839-866. DOI: 10.1071/MF99078

Hoegh-Guldberg O, Mumby PJ, Hooten AJ, Steneck RS, Greenfield P, Gomez E, et al. 2007. Coral reefs under rapid climate change and ocean acidification. Science 318: 1737-1742. DOI: 10.1126/science. 1152509

Hohenegger J. 2006. The importance of symbiont-bearing benthic foraminifera for West Pacific carbonate beach environments. Mar Micropaleontol 61: 4-39. DOI: 10.1016/j.marmicro.2006.05.007.

Sweatman HS, Delean S, Syms C. 2011. Assessing loss of coral cover on Australia's Great Barrier Reef over two decades, with implications for longer-term trends. Coral Reefs 30: 521-531. DOI: 10.1007/s00338010-0715-1.

Hughes TP. 1994. Catastrophes, phase shifts, and large-scale degradation of a Caribbean coral reef. Science 301: 929-933.

Hughes TP, Baird AH, Bellwood DR, Card M, Connolly SR, Folke C, Grosberg R, Hoegh-Guldberg O, Jackson JBC, Kleypas J, Lough JM, Marshall PA, Nyström M, Palumbi SR, Pandolfi JM, Rosen B, Roughgarden J. 2003. Climate change, human impacts, and the resilience of coral reefs. Science 301: 929-933.

Kitchell JF, O'Neill RV, Webb D, Gallepp GW, Bartell SM, Koonce JF, Ausmus BS. 1979. Consumer regulation of nutrient cycling. Bioscience 29: 28-34.

Loeblich AR, Tappan H. 1994. Foraminifera of the Sahul Shelf and Timor Sea. Cushman Foundation Spec. Pub. No. 31: 661p.

Marshall P, Schuttenberg H. 2006. Adapting coral reef management in the face of climate change. In: Phinney JT, Hoegh-Guldberg O, Kleypas J, Skirving W, Strong A (eds.). Coastal and Estuarine Studies. American Geophysical Union \& John Wiley \& Sons Inc., New York. DOI: $10.1029 / 61 \mathrm{CE} 13$.

McClanahan T. 2011. Coral reef fish communities in management systems with unregulated fishing and small fisheries closures compared with lightly fished reefs-Maldives vs. Kenya. Aquat Conserv Mar Freshw Res 21: 186-198.

Mumby PJ, Dahlgren CP, Harborne AR, Kappel CV, et al. 2006. Fishing, trophic cascades, and the process of grazing on coral reefs. Science 311: 98-101

Murray JW. 2014. Ecology and Palaeoecology of Benthic Foraminifera. Routledge-Taylor \& Francis, London.

Narayan YR, Pandolfi JM. 2010. Benthic foraminiferal assemblages from Moreton Bay, South-East Queensland, Australia: Applications in monitoring water and substrate quality in subtropical estuarine environments. Mar Pollut Bull 60: 2062-2078.

Pisapia C, El Kateb A, Hallock P, Spezzaferri S. 2017. Assessing coral reef health in the North Ari Atoll (Maldives) using the FoRAM index. Mar Micropaleontol 133: 50-57.

Prazeres M, Martínez-Colón M, Hallock P. 2020. Foraminifera as bioindicators of water quality: The FoRAM Index revisited. Environ Pollut 257: 113612. DOI: 10.1016/j.envpol.2019.113612.

Prazeres M, Renema W. 2019. Evolutionary significance of the microbial assemblages in large benthic foraminifera. Biol. Rev. 94, 828-848.

Ramirez A, Daniels C, Hallock P. 2008. Applications of the SEDCON and FORAM Indices on patch reefs in Biscayne National Park, FL, USA. Proc. 11th Intl Coral Reef Symp 4: 77-81.

Renema W. 2010. Is increased calcarinid (foraminifera) abundance indicating a larger role for macro-algae in Indonesian Plio-Pleistocene coral reefs? Coral Reefs 29: 165-173.

Rogers CS. 1990. Responses of coral reefs and reef organisms to sedimentation. Marine Ecol Progress Series 62: 185-202.

Uthicke S, Nobes K. 2008. Benthic foraminifera as ecological indicators for water quality on the Great Rarrier Reef. Estuar Coast Shelf Sci 78: 763-773.

Uthicke S, Thompson A, Schaffelke B. 2010. Effectiveness of benthic foraminiferal and coral assemblages as water quality indicators on inshore reefs of the Great Barrier Reef, Australia. Coral Reefs 29: 209-225. 
Table 1. Abundance of Foraminifera in Tunda Island waters

\begin{tabular}{|c|c|c|c|c|c|c|c|c|c|c|}
\hline Species & f1 & f2 & $\mathbf{f 3}$ & f4 & f5 & f6 & f7 & f8 & f9 & f10 \\
\hline Alveolinella quoyi d'Orbigny & 0 & 0 & 0 & 1 & 0 & 0 & 0 & 0 & 0 & 0 \\
\hline Ammonia beccarii Linne & 0 & 0 & 0 & 0 & 4 & 0 & 0 & 0 & 0 & 13 \\
\hline Ammonia tepida Cushman & 1 & 0 & 2 & 0 & 0 & 12 & 4 & 0 & 0 & 21 \\
\hline Amphistegina lessonii d'Orbigny & 6 & 3 & 3 & 3 & 3 & 21 & 3 & 0 & 14 & 3 \\
\hline Anomalinoides globulosus Chapman and Parr & 0 & 1 & 0 & 0 & 0 & 0 & 0 & 2 & 0 & 1 \\
\hline Asterorotalia trispinosa THALMANN & 0 & 0 & 0 & 0 & 1 & 0 & 0 & 0 & 0 & 0 \\
\hline Bigenerina nodosaria d'Orbigny & 0 & 0 & 1 & 0 & 0 & 0 & 0 & 0 & 0 & 0 \\
\hline Bolivina antiqua d'Orbigny & 0 & 0 & 0 & 0 & 0 & 1 & 0 & 0 & 1 & 0 \\
\hline Bolivina nitida Brady & 0 & 1 & 1 & 0 & 0 & 0 & 0 & 0 & 0 & 0 \\
\hline Bolivina sphatulata Williamson & 0 & 1 & 0 & 1 & 1 & 1 & 1 & 0 & 0 & 0 \\
\hline Buliminoides williamsonus Brady & 0 & 0 & 1 & 0 & 0 & 0 & 0 & 0 & 0 & 0 \\
\hline Calcarina calcar d'Orbigny & 0 & 5 & 0 & 15 & 15 & 6 & 17 & 60 & 13 & 5 \\
\hline Caribbeanella ogiensis Matsunaga & 0 & 0 & 0 & 0 & 0 & 0 & 0 & 2 & 0 & 1 \\
\hline Cymbaloporetta bradyi Cushman & 1 & 2 & 2 & 0 & 0 & 1 & 0 & 6 & 5 & 1 \\
\hline Dentalina plebeia Reuss & 0 & 0 & 1 & 0 & 0 & 1 & 0 & 0 & 3 & 0 \\
\hline Elphidium advenum Cushman & 5 & 0 & 7 & 0 & 0 & 10 & 1 & 4 & 5 & 2 \\
\hline Elphidium jenseni Cushman & 2 & 8 & 2 & 2 & 2 & 7 & 21 & 6 & 1 & 1 \\
\hline Elphidium macellum Fichtell \& Moll & 0 & 9 & 3 & 3 & 3 & 10 & 6 & 20 & 0 & 11 \\
\hline Elphidium vitreum Collins & 0 & 0 & 0 & 0 & 0 & 1 & 0 & 0 & 0 & 0 \\
\hline Eponides rephandus Fichtell \& Moll & 0 & 0 & 2 & 0 & 0 & 0 & 0 & 0 & 0 & 0 \\
\hline Eupatellinella fastidiosa Mc.Culloh & 0 & 1 & 4 & 0 & 0 & 8 & 0 & 0 & 1 & 0 \\
\hline Fijiella simplex Cushman & 0 & 1 & 0 & 0 & 0 & 2 & 0 & 2 & 0 & 0 \\
\hline Florensina philippinensis Mc.Culloh & 0 & 0 & 0 & 0 & 0 & 2 & 0 & 0 & 0 & 0 \\
\hline Heterolepa ornata Cushman & 2 & 5 & 2 & 4 & 4 & 25 & 0 & 0 & 1 & 0 \\
\hline Hyalinea baithica Schroeter & 0 & 0 & 0 & 0 & 0 & 0 & 2 & 0 & 0 & 0 \\
\hline Loxostomum limbatum Brady & 0 & 0 & 3 & 0 & 0 & 1 & 0 & 0 & 0 & 0 \\
\hline Loxostomum porrecta Brady & 0 & 0 & 0 & 0 & 0 & 1 & 0 & 0 & 1 & 0 \\
\hline Massilina granulocostata Germeraad & 0 & 15 & 2 & 0 & 0 & 1 & 0 & 16 & 7 & 1 \\
\hline Miliolinella suborbicularis d'Orbigny & 0 & 2 & 0 & 0 & 1 & 0 & 0 & 4 & 0 & 0 \\
\hline Milliolinella heligmaterra Loeblich \& Tappan & 1 & 0 & 1 & 0 & 0 & 0 & 0 & 0 & 0 & 0 \\
\hline Neoconorbina petasiformis T.C.Cheng\&Zheng & 0 & 1 & 6 & 0 & 0 & 47 & 0 & 0 & 10 & 1 \\
\hline Oolina globosa Montagu & 0 & 0 & 0 & 0 & 0 & 1 & 0 & 0 & 3 & 0 \\
\hline Operculina complanata DeFrance & 0 & 2 & 0 & 0 & 0 & 15 & 0 & 0 & 3 & 5 \\
\hline Orbulina universa d'Orbgny & 0 & 8 & 0 & 0 & 0 & 0 & 0 & 42 & 0 & 1 \\
\hline Peneroplis carinatus d'Orbigny & 5 & 33 & 16 & 14 & 14 & 28 & 20 & 56 & 13 & 67 \\
\hline Peneroplis pertusus Forskal & 2 & 36 & 12 & 22 & 22 & 27 & 14 & 132 & 37 & 54 \\
\hline Peneroplis planatus Fichtell \& Moll & 0 & 0 & 0 & 0 & 0 & 0 & 0 & 0 & 1 & 0 \\
\hline Pleurostomella sp.nov & 0 & 0 & 0 & 0 & 0 & 1 & 0 & 0 & 1 & 0 \\
\hline Pseudomassilina macilenta Brady & 0 & 0 & 0 & 0 & 0 & 1 & 0 & 0 & 0 & 0 \\
\hline Pseudorotalia schroeteriana Parker \& Jones & 5 & 35 & 57 & 14 & 14 & 73 & 32 & 292 & 159 & 4 \\
\hline Pygmaeoseistron islandicum R.W.Jones & 0 & 0 & 0 & 0 & 0 & 1 & 0 & 0 & 0 & 0 \\
\hline Quinqueloculina cuvieriana d'Orbigny & 5 & 5 & 16 & 0 & 0 & 15 & 3 & 46 & 19 & 7 \\
\hline Quinqueloculina incisa Vella & 0 & 18 & 6 & 2 & 2 & 10 & 5 & 40 & 9 & 4 \\
\hline Quinqueloculina parkeri Brady & 0 & 0 & 0 & 0 & 0 & 0 & 0 & 10 & 1 & 0 \\
\hline Quinqueloculina seminulina Linne & 12 & 11 & 3 & 2 & 2 & 1 & 2 & 6 & 5 & 17 \\
\hline Rectobolivina columellaris Brady & 0 & 1 & 0 & 0 & 0 & 0 & 0 & 0 & 0 & 0 \\
\hline Rosalina bradyi Cushman & 0 & 3 & 2 & 7 & 7 & 0 & 8 & 0 & 0 & 2 \\
\hline Rosalina globularis d'Orbigny & 4 & 7 & 2 & 0 & 0 & 5 & 3 & 20 & 3 & 7 \\
\hline Spiroloculina excisa Cushman \& Todd & 0 & 0 & 6 & 0 & 0 & 2 & 0 & 0 & 1 & 0 \\
\hline Spiroloculina scrobiculata Cushman & 0 & 0 & 2 & 1 & 1 & 0 & 1 & 2 & 1 & 1 \\
\hline Spiroloculina subimpressa Parr & 0 & 0 & 0 & 0 & 0 & 1 & 0 & 0 & 0 & 0 \\
\hline Triloculinella pseudooblonga Zheng & 1 & 1 & 1 & 0 & 0 & 2 & 1 & 8 & 6 & 5 \\
\hline Tristix carinata Sidebottom & 1 & 0 & 0 & 0 & 0 & 0 & 0 & 0 & 0 & 0 \\
\hline
\end{tabular}

Table 2. Grain size and FI values

\begin{tabular}{|c|c|c|c|c|c|c|c|}
\hline Station & $>2 \mathrm{~mm}$ & $500 \mu \mathrm{m}-1 \mathrm{~mm}$ & $250-500 \mu \mathrm{m}$ & $125-250 \mu \mathrm{m}$ & 63-125 $\mu \mathrm{m}$ & $<63 \mu \mathrm{m}$ & FI \\
\hline F1 & 16 & 36 & 1 & 1 & 2 & 100 & 3.8 \\
\hline F2 & 3 & 27 & 11 & 11 & 5 & 450 & 5.1 \\
\hline F3 & 2 & 35 & 3 & 3 & 2 & 200 & 4.3 \\
\hline $\mathrm{F} 4$ & 0 & 14 & 18 & 18 & 6 & 200 & 3.9 \\
\hline F5 & 3 & 45 & 0 & 0 & 0 & 0 & 7.4 \\
\hline F6 & 0 & 14 & 10 & 10 & 11 & 1100 & 3.8 \\
\hline F7 & 3 & 24 & 0 & 0 & 2 & 150 & 6.4 \\
\hline F8 & 3 & 26 & 1 & 1 & 2 & 350 & 3.7 \\
\hline F9 & 1 & 32 & 16 & 16 & 6 & 300 & 5.6 \\
\hline
\end{tabular}

